\title{
Environmental Management Accounting Perception and Implementation in the Automobile Industry in Vietnam
}

\author{
Ngoc Hung TRAN ${ }^{1}$, Thanh Hien HOANG ${ }^{2}$, Thi Thuy Hanh NGUYEN ${ }^{3}$
}

Received: September 10, 2020 Revised: November 02, 2020 Accepted: November 16, 2020

\begin{abstract}
This study aims to investigate the factors which impact the possibility of Environmental Management Accounting (EMA) implementation in automobile companies in Vietnam. A survey was carried out with automobile enterprises' managers, getting 198 usable respondents, with data and theoretical model analyzed by using SPSS with EFA method. Results indicated that in Vietnamese automobile enterprises, the possibility of EMA implementation was driven by elements including motivation to reduce production costs, reactions to environmental issues, compliance to legislation, procedures and processes in the working environment which they are in business. The government and professional institutions should play a vital role in promoting EMA practices by issuing specific guidelines and continuous training. Besides, tax authorities should apply the favor policies such as tax incentives to stimulate interest enterprises to implement EMA. However, this study's results only reflect about $63.7 \%$ of the impact to the implementation of EMA in Vietnamese automotive enterprises, so there are still some other factors that should be found out in the future researches. This is the first attempt to systematically analyze enterprises' perception and willingness to apply EMA in Vietnamese automobile industry. This study contributes to not only the existing empirical literature of EMA but also enterprises' managers in Vietnam and other transitional economies.
\end{abstract}

Keywords: Environmental Management Accounting, Impact Factors, Automobile Industry

JEL Classification Code: M40, M41, M14

\section{Introduction}

In recent decades, environmental issues have become a serious concern throughout the world due to the increasing number of noticeable environmental threats to the human future. These include, but not limited to natural disasters such as hurricanes, tsunami, global warming or human-made disasters including oil spills, plastic solid waste, the over-

${ }^{1}$ First Author and Corresponding Author. Lecturer, Faculty of Accounting and Auditing, Industrial University of Ho Chi Minh City, Ho Chi Minh City, Vietnam [Postal Address: 12 Nguyen Van Bao St., Ward 4, Go Vap Dist., Ho Chi Minh City, 08408, Vietnam]

Email: tranngochung@iuh.edu.vn

${ }^{2}$ Lecturer, Institute of Socio - Economics Research, Duy Tan University, Da Nang, Vietnam. Email: hoangthanhhien@dtu.edu.vn

${ }^{3}$ Lecturer, Faculty of Accounting and Auditing, Industrial University of Ho Chi Minh City, Ho Chi Minh City, Vietnam.

Email: nguyenthithuyhanh@iuh.edu.vn

(c) Copyright: The Author(s)

This is an Open Access article distributed under the terms of the Creative Commons Attribution Non-Commercial License (https://creativecommons.org/licenses/by-nc/4.0/) which permits unrestricted non-commercial use, distribution, and reproduction in any medium, provided the original work is properly cited. use of non-renewable resources, polluted air etc. (Jones, 2010). In addition, fuel combustion, which originated from automotive industry, has been called the largest contributor to air pollutant emissions (Sharma \& Sharma, 2014). These incidents have given hostage to fortune, and therefore led to calling for global organizations to pay more attention on worldwide environmental problems (Lee, 2011). As a result, adopting cleaner and safer and friendlier environmental practices have become essential. At the same time, more and more people are aware about environmental problems with the help of increased media coverage (Burritt, Schaltegger, Kokubu, \& Wagner, 2003). And nowadays, corporate social responsibility (CSR) has become popular issues in enterprises' concerns. It has not only been one way of doing improvement of enterprise's image but also being considered as a weighting creteria for stakeholders' consideration, including FDI invesment, firm market value (Lee, 2020).CSR practices also plays communicating role between insiders and outsiders, and companies with good CSR performance can borrow more unsecured debt, including short-term, long-term. (Yoon \& Lee, 2019, Chen et al., 2020). 
On the other hand, according to the Vietnamese Automobile Industry Development Strategy until 2025, with a vision to 2035, the automotive industry in Vietnam must ensure the overall socio-economic efficiency as well as environmental requirements. Moreover, after joining the Comprehensive and Progressive Agreement for TransPacific Partnership (CTTPP), the Vietnamese automobile industry has to face challenges from powerful competitors in CPTPP members such as Canada, Japan and other countries. This means that Vietnamese automobile industry must also catch up with the trend of saving energy as well as meeting domestic demand, and participate in the worldwide manufacturing chain. Therefore, there is a great need for an efficient and scientific economic system to provide accounting information for the management of production and business activities in automobile manufacturing industry in Vietnam.

Environmental management accounting (EMA), as part of environmental accounting, may assist managements to address environmental impacts of organizations' activities, particularly by providing related environmental information for making decisions. Despite its lack of a definite boundary or definition, EMA has emerged as an interface between management accounting and environmental management (Bennett, Rikhardsson, \& Schaltegger, 2003). Various studies on EMA from different perspectives reflect the importance of accounting when pursuing environmental management strategies (Schaltegger, Viere, \& Zvezdov, 2012). There are a number of researches done on the environmental management systems and initiatives have been done in the developed economies (Hsiao, Chuang, Kuo, \& Yu, 2014). However, there is a lack of studies on EMA relating to its benefits and significances in developing countries (Jamil, Zuriana, Mohamed, Muhammad, \& Ali, 2015). For example, according to the work of Xiaomei (2004) in China and Jalaludin, Sulaiman, and Ahmad (2011) in Malaysia, the majority of enterprises in developing countries are still far behind in comparison to the advanced countries in terms of understanding and applying EMA techniques and methods. In this light, our study aims to examine the validity of EMA in the context of Vietnamese automobile industry by conducting a survey with 300 automobile enterprises' managers. The contribution of this paper is twofold.

Firstly, to the best of our knowledge, this is the first attempt to systematically analyze enterprises' perception and willingness to apply EMA in Vietnamese automobile industry. Therefore, our paper's results will contribute to not only the existing empirical literature of EMA but also enterprises' managers in Vietnam and other transitional economies.

Secondly, in the developing countries such as Vietnam, the adoption of EMA is affected not only by internal factors such as human resources, compliance to legislation but also by external factors such as market factors including competitors, customers etc. Therefore, by collecting the creditable data during research time by quantitative method, the findings of our research can be used for reference not only in extra research about EMA in different industries such as mining or chemical, but also for policy makers when considering the way to protect our environment.

The rest of this paper is organized as follows. Section 2 discusses the literature background that motivates the empirical strategy. Section 3 provides a description of research design, the datasets and empirical methodology. The empirical results are discussed in section 4, which is then followed by concluding remark section.

\section{Literature Review}

In 2001, the United Nations Division for Sustainable Development (UNDSD) (2001) considered the EMA systems under a view of providing both physical or monetary information for internal decision making. They stated that EMA information is used within organizations for calculating and making decisions. For physical procedures, it included calculating consumption about energies, materials, disposals. And for monetary procedures, it included revenue calculation, costs and savings which is considered relating to activities with a potential environmental impact".

Meanwhile, the International Federation of Accountants (IFAC) (2005) had stated the definition about EMA as the action of management about performance, concerning the environmental and economic issues. Its contents were not only about reporting and auditing, but also about other issues such as life-cycle costing, full-cost accounting, benefits assessment, and strategic planning etc.

According to Vasile and Man (2012), the traditional management accounting systems are inappropriate to provide adequate and relevant information in order to solve environmental overheads. This leads enterprises to lessen costs and benefits that they would achieve by adopting or applying EMA tools in appropriate ways (Christ \& Burritt, 2013). Recently, there have been many investigations in EMA in order to fill in this gaps, and researchers also point out that the implementation of EMA tools in enterprises is being affected by not only internal but also external factors (Mensah, 2014).

In recent years, there have been several researches being made in order to develop a comprehensive framework of EMA. The authors have had to reflect the following aspects including EMA definition; the way to use EMA's information; the ways to recognize and allocate monetary and non-monetary information which are related to enterprises' environmental activities (Jamil et al., 2015; Janković \& Krivačić, 2014). 
There are three integrated elements of EMA that make EMA become all-important for not only environmental management but also enhancing planning processes. In addition, these elements have been efficient in allocating and controlling costs, help provide better pricing strategies and effective performance evaluation (Vasile \& Man, 2012). They include:

The process of identifying, allocating, and analyzing financial and physical information - it could help assigning and analyzing the enterprises' activities and then allocating costs on the cause-and-effect relationship. The useful financial and non-financial information could be attained and help in increasing enterprises' values by determining their incurred environmental costs more accurately.

Environmental costs (internal and external) - there is general accepted opinion that environmental costs result from the enterprises' activities and can cause harm to both the society and the individual. The environmental costs can be expressed in both of monetary and non-monetary items (Bouten \& Hoozée, 2013). In order to enhance internal decision making processes, it should incorporate environmental costs into internal cost accounting regardless of their types (Janković \& Krivačić, 2014).

Environmental cost allocation - researches about EA show that these costs should be allocated directly to the relevant cost drivers (Chang, 2013). Identifying, analyzing and allocating environmental costs can also help the management to identify cost saving opportunities (De Beer \& Friend, 2006).

In any enterprise, the operating activities may cause certain costs to incur. However, when combining effective environmental management practices with other operating activities, this may result in benefits and cost savings. Moreover, if the enterprises could use accounting systems to find, identify and maximize financial savings in using resources including waste and energy emissions, it may help to reduce the enterprises' environmental impacts (Masanet-Llodra, 2006). In the study of Setthasakko (2010) and Jamil et al. (2015), they stated that there were some problems with collecting data about environmental issues. As a result, it seems hard to identify or analyze, and evaluate the performance about waste management and pollution prevention. It also posed a challenge in absorbing the EMA into the existing traditional accounting.

As usual, traditional accounting methods generally direct attention to the resources' cost employed and their accumulation without paying attention to activities; so, they do not offer the ideal framework capable of identifying necessary data (Jones, 2010; Vasile \& Man, 2012). In addition, traditional management accounting systems and practices may not provide sufficiently accurate information for environmental management and environment-related cost management (Gale, 2006). As a result, enterprises significantly underestimate both the costs and benefits of sound environmental management practices. In order to fill in this gap, there had been a recent worldwide trend on researching in the field of EMA, for example, the formation of the Expert Working Group in 1998, whose responsibility included discussions and negotiations of environmentallyfriendly practices. The members of this organization included national environmental agencies and ministries, international organizations, industry, accounting firms, academia, and United Nations agencies (Jasch, 2003). In 2001, the EWG published a report titled "Improving the Role of Government in the Promotion of Environmental Management Accounting (EMA)", describing certain principles and procedures related to EMA, focusing particularly on techniques to quantify environmental costs for the development of national EMA guidelines and framework. This report stated that both conventional cost accounting and non-environmental costs of the accounts are assumed to be hidden with respect to management (Farouk, Cherian, \& Jacob, 2012; Jasch, 2003).

Researching about the differences in adoption of environmental management practices in developed and developing countries, some conclusions were arrived at such as that environmental issues are less intense in developing economies compared to the developed countries (De Oliveira, Serra, \& Salgado, 2010; Kang, Stein, Heo, \& Lee, 2012). Confirming the above findings, Hsiao et al. (2014) revealed that in developed countries, the implementation of the EMS (which includes EMA) is done more intensively. Moreover, there was also a variation in the extent to which the enterprises implemented environmental management practices, as a result, it led to the different adoption of EMS in the comprehensiveness of its coverage and ambitiousness of its objectives (Phan \& Baird, 2015). There had also been different emphasis on different industries, such as there was more focus on manufacturing, chemicals, farming etc. but limited research was done on the service industries like hotel industry (Chan \& Hawkins, 2012). And in their study, Qian, Burritt, and Chen (2015) also pointed out that the main focus of EMA studies have been on highly polluting and energy intensive industries.

Concerning about factors which impact the EMA adoption among manufacturing enterprises in Malaysia, Jalaludin et al. (2011) had collected ideas of 74 accountants who were interviewed and it was concluded from their interviews that they were pressurized by their customers, shareholders, head office and the government in terms of environmental performance. This pressure has an effect on their management accounting practices, including EMA adoption through the influence on their enterprise policy.

In their research conducted in 2015, Jamil et al. (2015) found that coercive factors have a significant influence on EMA practices, and with increasing coercive pressures, manufacturing SMEs are more willing to practice EMA 
(Jamil et al., 2015). Their result is in line with the prior results of Chang (2007), DiMaggio and Powell (1983), in which they stated that social, economic and political institutions may impact an enterprise's behavior and cause them to make changes and adopt new practices. Under the coercive pressures exerted by the government and legalization, organizations were forced to make changes and adopt certain attributes to gain legitimacy for their operations, such as adopting new techniques due to the need to comply with environmental regulations. In addition, their finding also shows that financial constraint is an important factor which limits the development of EMA in the manufacturing SMEs. Besides, other factors such as the insufficient environmental knowledge (with regards to true costs and benefits), employees' skills also contributed to the restriction of incorporating environmental issues into the traditional accounting systems and practices.

To summarize, EMA as part of environmental accounting, may assist management to address environmental impacts of organizations' activities, particularly by providing related environmental information for making decisions. However, in the developing economy such as Vietnam, the adoption of EMA is affected not only by internal factors such as human resources, compliance to legislation but also by external factors such as market factors etc. When joining the agreement, CTTPP which came into force on December 30th, 2018, the Vietnamese automobile industry had to face challenges from powerful competitors in Canada, Japan and other countries. Meanwhile, according to the Vietnamese Automobile Industry Development Strategy until 2025, with a vision to 2035 , the automotive industry must ensure the overall socio-economic efficiency as well as environmental requirements. In addition, it must also catch up with the trend of saving energy as well as meet with the domestic demand; and participate in the worldwide manufacturing chain. Therefore, there is a great need for an efficient and scientific economic system to provide accounting information for production management and business activities in automobile manufacturing industry in Vietnam.

\section{Research Design}

\subsection{Hypothesizes and Research Model}

The institutional theory explores how organizational structure and actions are shaped by surrounding institutional forces, including the governmental offices, the professional bodies and social organizations (DiMaggio \& Powell, 1983). Based on the isomorphic concept, this theory explains how coercive pressures, mimetic pressures and normative pressures occur during the organizational activities. Firstly, under coercive pressures, enterprises are forced to respect and strictly follow existing regulations issued by the government and the regulatory bodies. Secondly, when operating in fluctuating markets with uncertain situations, enterprises should increase their competetive advantages by mimicking proven techniques or practices from others, so the mimetic pressures occur. Thirdly, in order to mitigate coercive pressures, enterprises should voluntarily adopt existing rules and regulations, so that normative pressures occur during these processes. And according to DiMaggio and Powell (1983), there were slight distinction among three types of pressures and they are always interactive. Later, in his research, Chang (2007) had emphasized that as organizations' behavior is being pressurized by the society, economic and legal institutions, it forces them to make changes and adopt new practices.

In 2015, when doing research about EMA practices in small and medium manufacturing firms in Malaysia, Jamil et al. had mentioned that coercive factors have a significant influence on EMA practices. The results showed that Malaysian manufacturing SMEs are more willing to practice EMA under increasing coercive pressures (Jamil et al., 2015). They had concluded that increasing coercive pressures by the government would positively affect the intention and willingness of Malaysian manufacturing SMEs to adopt EMA practices. This result was in line with content of previous researches concerning the institutional theory (Chang, 2007; DiMaggio \& Powell, 1983). Their findings also indicated that there were some constraints which were considered as the main barriers in the development of EMA in Malaysian manufacturing SMEs, including financial constraint, deficient environmental knowledge (regarding full costs and benefits), unskillful employees, and lack of EMA's guidelines. It causes problems when accommodating environmental issues into the existing traditional accounting systems. This result is congruous with the previous research of Setthasakko (2010), in which he argued enterprises could face troubles in collecting, identifying, analyzing and evaluating environmental data due to the lack of guidance on EMA practices. As a result, it leads to a challenge to environmental performance evaluation and benchmarking, especially in waste management and pollution prevention.

Besides pressure and barriers to EMA practices, there are some common benefits that could motivate organizations to be compliant with the environmental sustainability, responding to stakeholder influences and achieving competitive advantage (Burritt et al., 2003; Doody, 2010). According to Gray and Bebbington (2001), these motivations can be broadly divided into legislative or market-based motivations which can lead to additional revenue streams and cost-saving opportunities for an organization (Bennett et al., 2003; Burritt et al., 2003; Doody, 2010; Lee, 2011; Schaltegger \& Burritt, 2006). 
Despite that automobile industry is considered as a key industry in Government's strategy development stage $2020-2025$, however, after nearly 20 years of establishing and developing, up to now, the supporting industry for Vietnamese automobile industry is still underdeveloped in terms of quantity, capacity, types and quality of products. According to the Ministry of Industry and Trade, there are only about 300 industrial supporting enterprises for the Vietnamese automobile industry but more than $90 \%$ of them are foreign-invested (FDI) enterprises. In Vietnamese automobile industry, under coercive pressures exerted by the government and legal bodies (such as VAMA) can compel automobile enterprises to make them changes and adopt certain attributes to gain legitimacy for their operations (including accounting procedures and other practices related to the environmental management). Concerning to EMA practices, coercive pressures can lead them to adopt new techniques due to the need to comply with Vietnamese environmental regulations. In addition, in the global integration trend, Vietnamese automobile enterprises have also faced mimetic pressures and normative pressures because nowadays there have been some large multi-national corporations such as Ford, Toyota, Honda, Mitsubishi etc. in Vietnam. So in order to increase their competitiveness, they should learn and mimic new techniques from not only their competitors but also their partners. Concerning motivations which are general in nature, there are more specific factors/reasons that have been identified in relation to the environmental strategies in the automobile sector. Governments have issued some policies to encourage foreign companies to invest in the production of hi-tech products in Vietnam. Due to the increasing awareness of Vietnamese consumers, automobile enterprises are encouraged to adopt EMA like a good way to advertise their brands and images, so that they are able to increase their revenue and profit.
Based on basis of the above discussion, the following hypotheses are developed:

$\boldsymbol{H}_{\boldsymbol{r}}$ : The benefit will have a positive impact on the possibility of implementation of EMA in Vietnamese automobile enterprises.

$\boldsymbol{H}_{2}$ : The coercive pressure will have a positive impact on the possibility of implementation of EMA in Vietnamese automobile enterprises.

$\boldsymbol{H}_{3}$ : The normative pressure will have a positive impact on the possibility of implementation of EMA in Vietnamese automobile enterprises.

$\boldsymbol{H}_{4}$ : The mimetic processes will have a positive impact on the possibility of implementation of EMA in Vietnamese automobile enterprises.

$\boldsymbol{H}_{5}$ : The barriers will have a negative impact on the possibility of implementation of EMA in Vietnamese automobile enterprises.

The model is as below:

$$
\begin{aligned}
\operatorname{POSS}_{\mathrm{i}}= & \alpha+\beta_{1} \mathrm{BEN}_{\mathrm{i}}+\beta_{2} \mathrm{COR}_{\mathrm{i}}+\beta_{3} \mathrm{NOR}_{\mathrm{i}}+\beta_{4} \mathrm{MIM}_{\mathrm{i}} \\
& +\beta_{5} \mathrm{BAR}_{\mathrm{i}}+\varepsilon
\end{aligned}
$$

where:

- POSS $_{\mathrm{i}}$ : possibility of implementation of EMA in Vietnamese automobile enterprises

- $\alpha$ : constant term

$-\beta_{i}$ : coefficient of variables

$-\varepsilon_{i}:$ Residual

The variables include BEN, COR NOR, MIM and BAR will represent for the benefit gained when implementing EMA, the coercive pressure, the normative pressure, mimetic processes and barriers on the possibility of implementation of EMA in Vietnamese automobile enterprises.

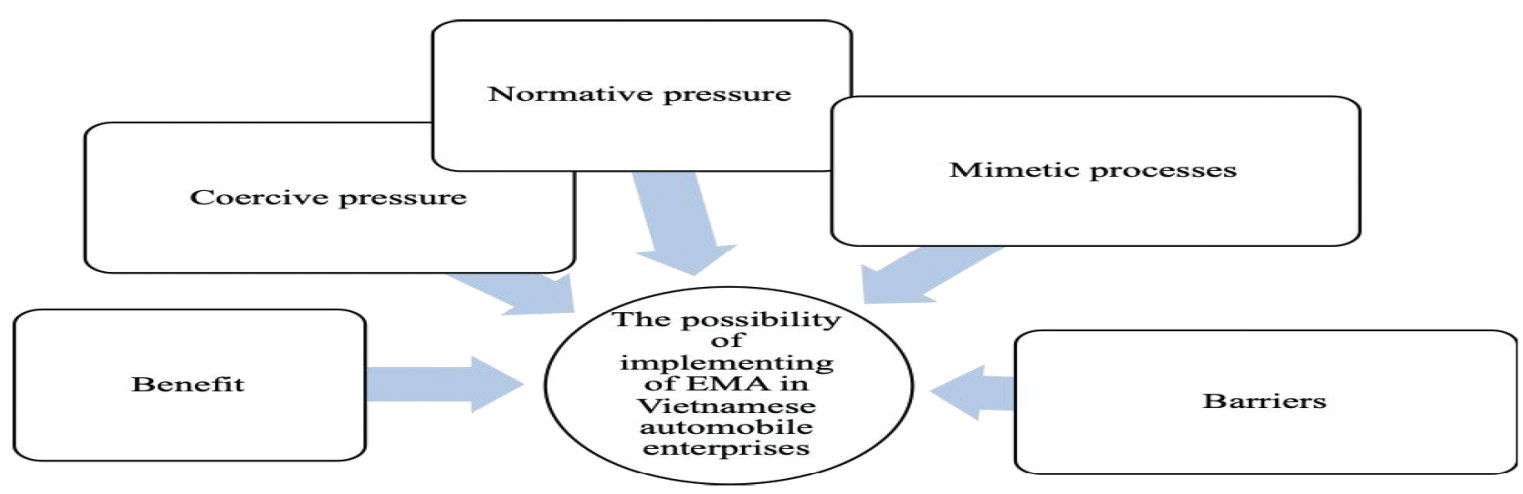

Figure 1: Overview of research 


\subsection{Data Collection Method}

During the research process, data were collected using both quantitative and qualitative methods. Firstly, in general research we apply the qualitative methodology in order to find out factors (variables) which can impact the possibility of implementation of EMA in Vietnamese automobile enterprises, and then adjust and add more factors by the techniques group discussion and interviewed experts. Secondly, in detailed research all of variables are measured by quantitative method by collecting data through choosing samples and sending questionnaires. Using the software SPSS 20.0 to check the model research, theoretical model and hypothesizes with EFA method. We had sent 300 samples of questionnaires to automobile enterprises' managers, and received the feedback of 198 usable ones. The response rate of $66 \%$ was higher than expected since EMA is still a new accounting appliance in Vietnam, but it determines that automobile industry is highly competitive, not only by local but also by multinational groups.

\section{Findings}

Using software SPSS 20.0 with Exploratory Factor Analysis, we have some results as below:

$0.5<\mathrm{KMO}<1$

Sig. $<0.05$

$\%$ cumulative variance $=62.5 \%$

Renamed independent variables into 5 scales and continue testing their reliability, we have all of 5 scales with the appropriate reliability (their Cronbach's Alpha > 0.6)
- BENEFIT: (F1) including variables MIM1, NOR2, COR12, MIM3, NOR3, COR9, BEN1 and BEN2;

- MIMETIC PROCESS: (F2) including variables COR5, COR11, BEN6, BAR10, MIM4, MIM2 and COR8;

- BARRIER: (F3) including variables BAR6, BAR7 and BAR4;

- BARRIER - 1: (F4) including variables BAR1 and BAR2;

- COERCIVE PRESSURE: (F5) including variables BEN8 and COR3;

Continue with Multiple Regression Analysis (MRA) we have the final result as below

- For Coefficients testing: we have 4 of variables F1, F2, F3 and F4 have Sig. $<0.05$ so they are appropriate with variable POSS (possibility of implementing management accounting in SMEs in Vietnam). The other variable F5 is not appropriate meaning with variable POSS because they have Sig. $>0.05$.

- For Model appropriation testing, the adjusted R square is 0.637 , it means that $63.7 \%$ of the change of possibility of implementing EMA in Vietnamese automobile enterprises being explained by variables F1, F2, F3 and F4.

- For ANOVA, we have Sig. $<0.01$, so we can conclude that independent variables have linear correlation with dependent variable.

The regression analysis results in the table above confirms the supported hypotheses ( $P_{-}$value $\left.<0.01\right)$. The impact level of each factor is shown in the table below:

Table 1: KMO and Bartlett's test

\begin{tabular}{|l|l|c|}
\hline Kaiser-Meyer-Olkin Measure of Sampling Adequacy & .920 \\
\hline \multirow{3}{*}{ Bartlett's Test of Sphericity } & Approx. Chi-Square & 4004.340 \\
\cline { 2 - 3 } & Df & 666 \\
\cline { 2 - 3 } & Sig. & .000 \\
\hline
\end{tabular}

Table 2: Model Summary

\begin{tabular}{|c|c|c|c|c|c|c|c|c|c|c|}
\hline \multirow[b]{2}{*}{ Model } & \multirow[b]{2}{*}{$\mathbf{R}$} & \multirow{2}{*}{$\begin{array}{c}\mathbf{R} \\
\text { Square }\end{array}$} & \multirow{2}{*}{$\begin{array}{c}\text { Adjusted R } \\
\text { Square }\end{array}$} & \multirow{2}{*}{$\begin{array}{l}\text { Std. Error of } \\
\text { the Estimate }\end{array}$} & \multicolumn{5}{|c|}{ Change Statistics } & \multirow{2}{*}{$\begin{array}{l}\text { Durbin- } \\
\text { Watson }\end{array}$} \\
\hline & & & & & $\begin{array}{c}\text { R Square } \\
\text { Change }\end{array}$ & $\begin{array}{c}\text { F } \\
\text { Change }\end{array}$ & df1 & df2 & $\begin{array}{c}\text { Sig. F } \\
\text { Change }\end{array}$ & \\
\hline 1 & $.804 a$ & .646 & .637 & .60235053 & .646 & 70.192 & 5 & 192 & .000 & 2.132 \\
\hline
\end{tabular}

a. Predictors: (Constant), REGR factor score 1 for analysis 5, REGR factor score 1 for analysis 3 , REGR factor score 1 for analysis 4 , REGR factor score 1 for analysis 2, REGR factor score 1 for analysis 1

b. Dependent Variable: REGR factor score 1 for analysis 6 
Ngoc Hung TRAN, Thanh Hien HOANG, Thi Thuy Hanh NGUYEN /

Table 3: ANOVA analysis

\begin{tabular}{|c|l|c|c|c|c|c|}
\hline \multicolumn{2}{|l|}{ Model } & Sum of Squares & Df & Mean Square & F & Sig. \\
\hline \multirow{3}{*}{1} & Regression & 127.337 & 5 & 25.467 & 70.192 & $.000^{\mathrm{b}}$ \\
\cline { 2 - 7 } & Residual & 69.663 & 192 & .363 & & \\
\cline { 2 - 7 } & Total & 197.000 & 197 & & & \\
\hline
\end{tabular}

a. Dependent Variable: REGR factor score 1 for analysis 6

b. Predictors: (Constant), REGR factor score 1 for analysis 5, REGR factor score 1 for analysis 3, REGR factor score 1 for analysis 4 , REGR factor score 1 for analysis 2, REGR factor score 1 for analysis 1

Table 4: Estimation results

\begin{tabular}{|c|c|c|c|c|c|c|}
\hline \multicolumn{2}{|c|}{ Model } & \multicolumn{2}{|c|}{$\begin{array}{l}\text { Unstandardized } \\
\text { Coefficients }\end{array}$} & \multirow{3}{*}{$\begin{array}{c}\begin{array}{c}\text { Standardized } \\
\text { Coefficients }\end{array} \\
\text { Beta } \\
\end{array}$} & \multirow[t]{2}{*}{$\mathbf{t}$} & \multirow[t]{2}{*}{ Sig. } \\
\hline & & B & Std. Error & & & \\
\hline \multirow{6}{*}{1} & (Constant) & $-1.954 \mathrm{E}-016$ & .043 & & .000 & 1.000 \\
\hline & REGR factor score 1 for analysis 1 & .509 & .062 & .509 & 8.226 & .000 \\
\hline & REGR factor score 1 for analysis 2 & .121 & .062 & .121 & 1.968 & .050 \\
\hline & REGR factor score 1 for analysis 3 & .210 & .052 & .210 & 4.056 & .000 \\
\hline & REGR factor score 1 for analysis 4 & .142 & .051 & .142 & 2.786 & .006 \\
\hline & REGR factor score 1 for analysis 5 & .034 & .059 & .034 & .582 & .561 \\
\hline
\end{tabular}

a. Dependent Variable: REGR factor score 1 for analysis 6

Table 5: Results

\begin{tabular}{|l|c|c|}
\hline $\begin{array}{l}\text { Independent } \\
\text { Variables }\end{array}$ & Value & $\%$ \\
\hline F1 & 0.509 & 51.83 \\
\hline F3 & 0.210 & 21.39 \\
\hline F4 & 0.142 & 14.46 \\
\hline F2 & 0.121 & 12.32 \\
\hline Total & 0,982 & 100 \\
\hline
\end{tabular}

\section{Discussions and Conclusions}

Basing on the results above, we have the rank of importance of factors as below:

So, as a result, 4 factors including benefit gained when implementing EMA (BENEFIT), barriers when implementing EMA (BARRIER and BARRIER - 1) and mimetic processes (MIMETIC) will contribute 51.83\%, $21.39 \%, 14.46 \%$ and $12.32 \%$ impact on the implementation of EAM in Vietnamese automotive enterprises.

The above sections mention that benefit factors have a significant influence on the possibility of EMA implementation. With increasing benefits such as improving the product costs, increasing competitive advantage etc., Vietnamese automobile enterprises are more willing to implement EMA. In addition, the coercive factors also have an influence on EMA practices. Due to the strict compliance to the environmental laws and rules, it has been seen in the recent times that the Vietnamese automobile enterprises are keener to practice EMA. This results are in line with the prior researches that under the pressures of social, economic and political institutions the enterprises should make changes by themselves by selecting new practical tools. In addition, governmental coercive pressures can also force enterprises and adopt certain attributes to gain legitimacy for their operations. Regarding the EMA practices, enterprises may adopt new techniques because they have to comply with environmental regulations under coercive pressures. If the government does not create any pressure by issuing EMA's guidelines which force enterprises to apply EMA procedures, it seems impossible for them to adopt EMA as new accounting procedures and activities. Thus, increasing coercive pressures by the government would be a good way to seriously impact the intention and willingness of Vietnamese automobile enterprises in implementing EMA practices. Besides, the results also show that financial and managerial barriers are the main constraint in the development of EMA in the Vietnamese automobile enterprises. The lack of body of knowledge about EMA (regarding to full costs and benefits) and skills of labour resources are also considered as problems causing the restriction when incorporating the environmental issues into the traditional accounting systems. 
Finally, this study finds that the implementation of EMA in competitors, including both local and multi-national groups, can also affect the willingness to adopt the EMA practices in Vietnamese automobile enterprises.

This study has a number of implications. The Vietnamese government, especially The Ministry of Natural Resources and Environment, should play a vital role in promoting EMA practices by issuing specific guidelines and continuous trainings. Besides, tax authorities should apply the favored policies such as tax incentives to stimulate interest among Vietnamese automobile enterprises to implement EMA because the finding shows that financial constraint is also an important barrier that prevents them from implementing EMA. Accounting professional bodies including Vietnamese universities, professional institutions such as ACCA, CPA, ICAEW representatives in Vietnam etc. should also get involved in advocating EMA by issuing a detailed and clear framework for EMA activities. In conclusion, the pursuit of incorporating environmental issues into traditional accounting systems and practices require all related stakeholders to get involved, contribute greater corporate responsibility and proper guidance on EMA. However, due to the limitation of time and resource, the result of this study, with 04 factors, just only reflect about $63.7 \%$ of the impact in the implementation of EMA in Vietnamese automotive enterprises, so there are still some other factors which should be found out in the forthcoming research.

\section{References}

Bennett, M., Rikhardsson, P., \& Schaltegger, S. (2003). Adopting environmental management accounting: EMA as a valueadding activity. Environmental Management AccountingPurpose and Progress (pp. 1-14): Springer.

Bouten, L., \& Hoozée, S. (2013). On the interplay between environmental reporting and management accounting change. Management Accounting Research, 24(4), 333-348.

Burritt, R. L., Schaltegger, S., Kokubu, K., \& Wagner, M. (2003). Environmental management accounting for staff appraisal: Evidence from Australia, Germany and Japan Environmental Management Accounting-Purpose and Progress (pp. 151-188). New York, NY: Springer.

Chan, E. S., \& Hawkins, R. (2012). Application of EMSs in a hotel context: A case study. International Journal of Hospitality Management, 31(2), 405-418.

Chang, H. (2007). Environmental management accounting within universities: Current state and future potential. $\mathrm{PhD}$ Thesis, RMIT University.

Chang, H. C. (2013). Environmental management accounting in the Taiwanese higher education sector. International Journal of Sustainability in Higher Education, 14(2), 133-145.

Chen, X. et al. (2020). Corporate Social Responsibility and Unsecured Debt: Evidence from China. Journal of Asian
Finance, Economics and Business, 7(11) 001-011 http:// doi:10.13106/jafeb.2020.vol7.no11.001

Christ, K. L., \& Burritt, R. L. (2013). Environmental management accounting: The significance of contingent variables for adoption. Journal of Cleaner Production, 41, 163-173.

De Beer, P., \& Friend, F. (2006). Environmental accounting: A management tool for enhancing corporate environmental and economic performance. Ecological Economics, 58(3), 548-560.

De Oliveira, O. J., Serra, J. R., \& Salgado, M. H. (2010). Does ISO 14001 work in Brazil? Journal of Cleaner Production, 18(18), 1797-1806.

DiMaggio, P. J., \& Powell, W. W. (1983). The iron cage revisited: Institutional isomorphism and collective rationality in organizational fields. American Sociological Review, 147-160.

Doody, H. (2010). Environmental sustainability: tools and Techniques. Society of Management Accountants of Canada, the American Institute of Certified Public Accountants.

Economic, D. O., Nations, S. A. U., \& Österreich, B. f. V. (2001). Environmental management accounting procedures and principles. New York, NY: United Nations.

Farouk, S., Cherian, J., \& Jacob, J. (2012). Green Accounting and Management for Sustainable Manufacturing in Developing Countries. International Journal of Business and Management, $7(20)$.

Gale, R. (2006). Environmental management accounting as a reflexive modernization strategy in cleaner production. Journal of Cleaner Production, 14(14), 1228-1236.

Gray, R., \& Bebbington, J. (2001). Accounting for the Environment. Thousand Oaks, CA: Sage Publications.

Hsiao, T. Y., Chuang, C. M., Kuo, N. W., \& Yu, S. M. F. (2014). Establishing attributes of an environmental management system for green hotel evaluation. International Journal of Hospitality Management, 36, 197-208.

Jalaludin, D., Sulaiman, M., \& Ahmad, N. N. N. (2011). Understanding environmental management accounting (EMA) adoption: A new institutional sociology perspective. Social Responsibility Journal, 7(4), 540-557.

Jamil, M., Zuriana, C., Mohamed, R., Muhammad, F., \& Ali, A. (2015). Environmental management accounting practices in small medium manufacturing firms. Procedia-Social and Behavioral Sciences, 172, 619-626.

Janković, S., \& Krivačić, D. (2014). Environmental accounting as perspective for hotel sustainability: Literature review. Tourism and Hospitality Management, 20(1), 103-120.

Jasch, C. (2003). The use of Environmental Management Accounting (EMA) for identifying environmental costs. Journal of Cleaner Production, 11(6), 667-676.

Jones, M. J. (2010). Accounting for the environment: Towards a theoretical perspective for environmental accounting and reporting. Paper presented at the Accounting Forum.

Kang, K. H., Stein, L., Heo, C. Y., \& Lee, S. (2012). Consumers' willingness to pay for green initiatives of the hotel industry. 
Ngoc Hung TRAN, Thanh Hien HOANG, Thi Thuy Hanh NGUYEN /

International Journal of Hospitality Management, 31(2), 564-572.

Lee, J. W. (2020). CSR Impact on the Firm Market Value: Evidence from Tour and Travel Companies Listed on Chinese Stock Markets. Journal of Asian Finance, Economics and Business, 7(7), 159-167. https://doi.org/10.13106/jafeb.2020. vol7. no7.159

Lee, K. H. (2011). Motivations, barriers, and incentives for adopting environmental management (cost) accounting and related guidelines: a study of the republic of Korea. Corporate Social Responsibility and Environmental Management, 18(1), 39-49.

Masanet-Llodra, M. J. (2006). Environmental management accounting: a case study research on innovative strategy. Journal of Business Ethics, 68(4), 393-408.

Mensah, I. (2014). Stakeholder pressure and hotel environmental performance in Accra, Ghana. Management of Environmental Quality: An International Journal, 25(2), 227-243.

Phan, T. N., \& Baird, K. (2015). The comprehensiveness of environmental management systems: The influence of institutional pressures and the impact on environmental performance. Journal of Environmental Management, 160, 45-56.

Qian, W., Burritt, R., \& Chen, J. (2015). The potential for environmental management accounting development in China. Journal of Accounting \&amp; Organizational Change, 11(3), 406-428. doi:10.1108/JAOC-11-2013-0092
Schaltegger, S., \& Burritt, R. (2006). Corporate Sustainability Accounting. A Catchphrase for Compliant Corporations or a Business Decision Support for Sustainability Leaders? In: Sustainability accounting and reporting (pp. 37-59). New York, NY: Springer.

Schaltegger, S., Viere, T., \& Zvezdov, D. (2012). Tapping environmental accounting potentials of beer brewing: Information needs for successful cleaner production. Journal of Cleaner Production, 29, 1-10.

Setthasakko, W. (2010). Barriers to the development of environmental management accounting: An exploratory study of pulp and paper companies in Thailand. EuroMed Journal of Business, 5(3), 315-331. doi:10.1108/14502191011080836

Sharma, R., \& Sharma, N. (2014). Environmental impact of automobiles in India. Journal of Basics and Applied Engineering Research, 1(2).

Vasile, E., \& Man, M. (2012). Current dimension of environmental management accounting. Procedia-Social and Behavioral Sciences, 62, 566-570.

Xiaomei, L. (2004). Theory and practice of environmental management accounting. International Journal of Technology Management \& Sustainable Development, 3(1), 47-57.

Yoon, B., \& Lee, J.-H. (2019). Corporate Social Responsibility and Information Asymmetry in the Korean Market: Implications of Chaebol Affiliates. Journal of Asian Finance, Economics and Business, 6(1), 21-31. http://doi.org/10.13106/jafeb.2019.vol6. no1.21 